\title{
Zhou Xiaohong, Zhongguo shehui yu zhongguo yanjiu.
}

Beijing shehui kexue wenxian chubanshe, 2004, 722 p.

Jean-Louis Rocca

\section{OpenEdition}

\section{Journals}

Édition électronique

URL : http://journals.openedition.org/chinaperspectives/966

DOI : 10.4000/chinaperspectives.966

ISSN : 1996-4617

\section{Éditeur}

Centre d'étude français sur la Chine contemporaine

Édition imprimée

Date de publication : 15 février 2005

ISSN : 2070-3449

\section{Référence électronique}

Jean-Louis Rocca, «Zhou Xiaohong, Zhongguo shehui yu zhongguo yanjiu. », China Perspectives [En

ligne], 57 | january - february 2005, mis en ligne le 22 mai 2007, consulté le 23 septembre 2020. URL http://journals.openedition.org/chinaperspectives/966; DOI : https://doi.org/10.4000/

chinaperspectives.966

Ce document a été généré automatiquement le 23 septembre 2020.

(C) All rights reserved 


\section{Zhou Xiaohong, Zhongguo shehui yu zhongguo yanjiu.}

Beijing shehui kexue wenxian chubanshe, 2004, 722 p.

Jean-Louis Rocca

NOTE DE L'ÉDITEUR

Translated from the French original by Jonathan Hall

1 This volume is a collection of papers given at a conference with the same title, which was organised to celebrate the Nanjing University centenary in May 2002. Its goal is to review the development of what the editor, Zhou Xiaohong, calls "contemporary Chinese studies" (dangdai Zhongguo yanjiu) and to present a certain number of mainly Chinese works pertaining to that discipline. In his introduction Zhou shows that although this "interdisciplinary" (hengkua xueke) "field" (lingyu) originated in the United States, owing mainly to such figures as Fairbank, Vogel and Schumann, the reforms have allowed the emergence of new generations of Chinese researchers, many of whom-but not all-have been trained in the West. Zhou defines this field of study as "society, economy, politics, and culture in modern China".

2 Influenced by the political situation, the nature of the information available to it, and the confrontation of competing theories and methods, this field has undergone considerable changes. In the 1950s and 1960s it was a matter of grasping that tricky subject, "new China", within a functionalist framework (Parsons) and relying on official sources of information. Although the theoretical approach changed very little in the 1970s, the increasing amount of information from immigrants into Hong Kong gave it more solid grounds. Later, the possibility of conducting research on the spot led to a great increase in the number of problems being addressed, largely in the area of the relationship between society and the state, the public sphere, and civil society. Finally, the 1990s saw the discipline reach maturity, with the appearance of a new generation of Chinese sociologists and a growing interest in post-modernism. Zhou Xiaohong 
believes that contemporary Chinese studies are characterised by concerns with crossdisciplinarity and internationalisation. These are providing a bridge between Western and Chinese researchers, while China itself is becoming both a place for testing western theories and a source of inspiration for solving the problems facing the world.

3 All the major questions confronting Chinese society are broached in this volume. Among the most significant contributions (regrettably, they cannot all be mentioned) I would cite those by Lin Nan and Sun Liping on the "indigenisation" (bentuhua) of western theories, and those by Lu Xueyi, Song Lifei, Guan Xinping, and Lu Hanlong on different aspects of the "transition" (zhuanxing). The hotly debated question of the new "social structure" (shehui jiegou) is discussed, either in a global manner or through local research projects, by Zheng Hansheng, Liu Zuyun, Bian Yanjie and Zhang Zhanxin, $\mathrm{Hu}$ Rong, Lü Dale, Zhou Xiaohong and Zhang Jing. I should also mention the articles devoted to changes in urban society (Zhang Hongyan, Feng Gang and Li Youmei and Ye Nange) and in rural society (Zhang Letian, Li Peilin, Zhou Dawu and Zhu Li) as well as the contributions from Xu Anqi and Tong Xing, which deal with the family and corruption respectively.

Two points immediately spring to mind on reading these texts. The first concerns their high quality. I would recommend that anyone who still has some doubts about the level of Chinese sociological research, should give serious attention to this work, especially as there are a number of good Chinese sociologists whose work is not included here ${ }^{1}$. All the contributions are of very high calibre, both with regard to the questions raised and the methodological apparatus deployed. I will limit myself to citing those which touch on my own field, with apologies to all the other writers. Sun Liping's article offers a critique of what might be called "market transitionalism", which is a concept derived from the experience of Eastern European countries. He insists particularly on the specificity of the Chinese experience, and argues for another approach which would focus on actual practices, such as the mechanisms, logistics and techniques employed "on the ground" (zixia ershang). Lu Xueyi takes a fresh look at the crisis of the sannong (agriculture, villages and the peasantry) by offering a new inclusive view of its origins and principal features. For his part, Song Linfei provides a sort of genealogy of the idea of transition, with its many different translations and its multiplicity of meanings. Other outstanding and very enlightening studies that could be mentioned are Bian Yanjie and Zhang Zhanxin's contribution on the changing patterns of urban incomes, Lin Peilin's on "the end of the villages" (cunluo zhongjie), and Zhou Xiaohong on the middle class.

5 There is also the striking absence of Europe from this intellectual scene. Despite one or two minor references to French and English research, it would appear that researchers from the United States, and to a lesser extent Australia, have been the sole creators of contemporary Chinese studies. There is a large measure of truth in such an observation, but it is also somewhat misleading. Its truth is undeniable if one focuses on the paucity of references to German, French, Scandinavian or even English works in Chinese studies. But the partial nature of this truth emerges if account is taken of the qualitative contribution from the old World. European works exist, but they are not widely circulated in China. There are many explanations for this state of affairs. Naturally, these include the dominance of the English language, the lack of support, the break-up of research teams, and the difficulty which some have in submitting to the demanding norms for acceptance by Anglo-Saxon periodicals, the latter being an 
absolute precondition for the wider circulation of works in China. In this respect, it should be noted that China Perspectives plays an invaluable role. Nevertheless, among all these factors, the financial question seems primary. The influence of United States universities is sustained through enormous amounts of foundation funding, and this allows the organisation of Sino-American teams to investigate problems which are, of course, structured in conformity with the intellectual perspectives of the funding institutions.

6 This situation is particularly regrettable because, as the present volume amply shows, Chinese sociology is very receptive to European intellectual approaches. Even though the references by Li Youmei and Li Peilin to French writers can be attributed to the fact that they completed their studies in France, many of the other researchers, to give a more typical example, make implicit or explicit use of "qualitative" approaches grounded in a simultaneous concern with the "down-to-earth" and the need for a conceptual apparatus, and this represents a firm break with the empiricist strain in the American critical approach. I am not concerned here with fomenting a rivalry or asserting the superiority of one trend over another, but with defending an intellectual pluralism in which European researchers ought to be leading protagonists.

\section{NOTES}

1. I'm thinking particularly of Fei Lulu, Huang Ping, Jing Jun, Li Qiang, Shen Yuan, Tang Jun, Tong Xin and many others. 